\title{
Harvard heralds fresh take on systems biology
}

\section{Erika Check, Washington}

Harvard Medical School is to set up a department devoted to systems biology - the first entirely new department to be founded at the institution in 20 years.

Systems biology involves the integration of computer modelling, large-scale data analysis and biological experimentation. The 23 September announcement by the medical school at America's most famous university is seen as emblematic of the field's rapid rise - and the need to train a cadre of undergraduate and graduate students to work in it.

The department will be led by cell biologist Marc Kirschner, who pushed hard for its creation in the face of some resistance from established Harvard departments. Kirschner plans to recruit about 20 faculty members for the new department. Tim Mitchison of Harvard's cell biology department and Lewis Cantley of the Beth Israel Deaconess Medical Center have already decided to join the department. But Kirschner says that most of the rest will be recruited from outside the university.

Until now, most large US research universities, including the Massachusetts Institute of Technology and Stanford and Princeton universities, have sought to accommodate systems-biology expertise at interdisciplinary research institutes. Other centres, such as the Institute for Systems Biology in Seattle,

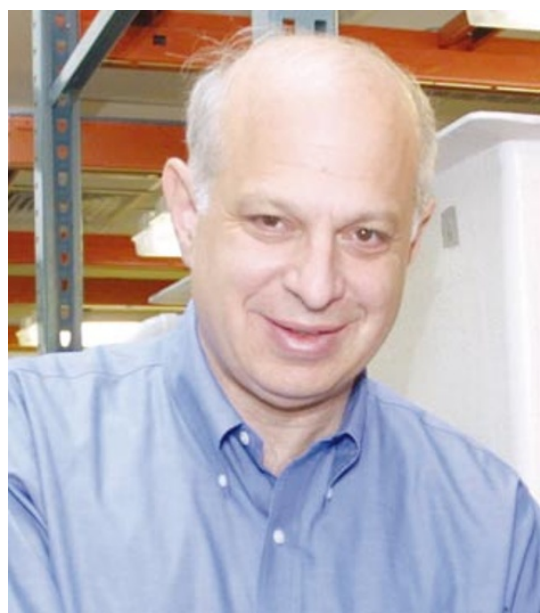

Teaching plan: Marc Kirschner campaigned for a facility to train students in quantitative biology.

Washington, have been set up independently, and yet other projects, such as the Alliance for Cellular Signaling, involve consortia of universities.

But by establishing a fully fledged department, Harvard hopes to incorporate undergraduate and graduate education into its work, says Joseph Martin, dean of the medical school.

The new department says it will cooperate closely with Harvard's Bauer Center for Genomics Research, set up just last year with its own mission of bringing expertise from mathematics and the physical sciences to bear on biological problems.

Other systems-biology researchers say the challenge for the department will be to create career incentives for people who will be working without the boundaries of traditional disciplines. The systems-biology approach involves large teams of people, and it will be difficult to determine how best to make decisions about issues such as how to award tenure, suggests Leroy Hood, president of the Institute for Systems Biology.

Hood also points out that granting agencies, such as the National Science Foundation, are structured to support traditional research disciplines, and sometimes struggle to maintain support for large interdisciplinary groups. "There's got to be a mixture of people who make contributions," Hood says. "You may have an array facility or a proteomics facility, but you need an awful lot more than that to do integrated systems biology."

But Kirschner says this is precisely why he wanted to create a full department. "The alternative would be to create collaborative interactions among different groups," he explains. "But we want to create a community of people whose main interest is in bringing quantitative mathematical approaches to complex systems. I think it has the best chance of working if the group is created with this primary focus."

\section{Adviser gears up to bring scientists to matters of state}

\section{Geoff Brumfiel, Washington}

George Atkinson's office window at the Department of State in Washington DC looks across the street to the National Academies, which advise the US government on scientific matters. But bringing the right technical expertise into the state department has been a perennial problem. As newly appointed science and technology adviser to the secretary of state, Atkinson is setting out to fix it.

He will take a small step towards that goal this week, when the department announces funding from the MacArthur Foundation, the Carnegie Foundation and a group of universities for a beefed-up scholarship programme that will pluck seasoned researchers from universities. After a year at the department, they will return to their jobs while also continuing as consultants with the state department for a further five years. Atkinson himself is a chemist on secondment from the University of Arizona at Tucson.

Atkinson took up his position on
23 September, succeeding

Norman Neureiter, a chemist and former manager at Texas Instruments. The post was created three years ago by then secretary of state Madeleine Albright, in response to a 1998 report from the National Academy of Sciences. The report noted that science and technology were "not receiving adequate

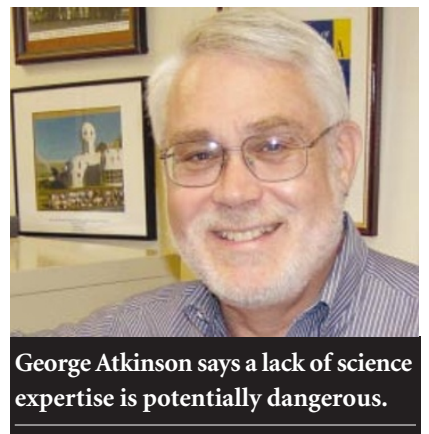

also hopes to devise more ways for researchers to act as consultants to the department when their fellowships are over. His office also plans to hold quarterly briefings for senior department officials on the latest developments in science and technology.

Atkinson faces a attention within the department" (see Nature 395, 313; 1998).

Despite a small increase since then in the number of scientists working with the department, Atkinson believes that lack of scientific expertise is still a "potentially dangerous situation". Many scientific issues, from carbon emissions to visa rulings for incoming researchers, fall in its remit.

The new funding will support 15 fellows over the next three years, Atkinson says. Besides increasing fellowship numbers, he busy time both at home and abroad, says Irving Lerch, head of international affairs at the American Physical Society. As well as dealing with domestic issues such as delays to visiting researchers' visa applications, Atkinson is expected to help rebuild Iraq's scientific infrastructure. The country's fledgling science agency has so far had little interaction with US scientists, says Lerch.

"I think that George is faced with a serious problem there."

www.state.gov/g/stas 